\title{
"It's Almost Like I Have a Job, but I Don't Get Paid": Fathers at Home Reconfiguring Work, Care, and Masculinity
}

\author{
ANDRea DouceT \\ Carleton University
}

\begin{abstract}
Rooted in a qualitative research project with 70 stay-at-home fathers in Canada, this paper explores the ways that work and family interact for fathers who "trade cash for care." While fathers are at home, they also remain connected to traditionally masculine sources of identity such as paid work and they take on unpaid masculine self-provisioning work at home and community work that builds on traditional male interests. They thus carve out complex sets of relations between home, paid and unpaid work, community work, and their own sense of masculinity. Narratives from stay-at-home fathers speak volumes about the ways in which the long shadow of hegemonic masculinity hangs over them while also pointing to hints of resistance and change as fathers begin to critique concepts of "male time" and market capitalism approaches to work and care. The paper concludes by pointing to several theoretical contributions to research on fatherhood and masculinities as well as to policy implications that arise from this study on the social valuing of unpaid work.
\end{abstract}

Keywords: stay-at-home fathers, home-work balances, masculinities and femininities

\begin{abstract}
I am grateful to the 120 fathers (including the 70 stay-at-home fathers) who gave generously of their time and insights to the research project that informs this paper as well as to the 14 mothers who were interviewed. Many thanks to my initial collaborators who assisted with the conceptualization of the project proposal (Martha MacDonald, Patricia M. Connelly, Martin Richards, and Oriel Sullivan); my excellent research assistants (Erin Mills, Phil Robinson, Maureen Flynn-Burhoe, Kelly McDonald, Chis Blahout, Pete Andrachyk, and Liz Hall); my colleagues who assisted with group data analysis (Janet Siltanen, Allete Willis, Willow Scobie, and Jen Budney); Carol Gilligan and Robert M. Blackburn, whose mentoring underpins this work; to two anonymous referees who provided excellent commentary and critique of this paper; and to editors Kerry Daly and Rob Palkovitz for valuable feedback. The project was funded by the Social Sciences and Humanities Research Council of Canada.
\end{abstract}

Correspondence concerning this article should be addressed to Andrea Doucet, Sociology and Anthropology, Carleton University, Ottawa, Canada, K1S 5B6. Electronic mail: andrea_doucet@ carleton.ca.

Fathering, Vol. 2, No. 3, Fall 2004, pp. 277-303.

CC 2004 by the Men's Studies Press, LLC. All rights reserved. 


\section{DOUCET}

It's funny. There were lots of pros and cons about being home.... One of the things I missed was that you lose a sense of stature, a sense of common ground between myself and other men, a sense of being able to say-'Hey, I'm a man too." I think a lot of that revolved around not having employment. Not working and being at home. For me not working was the bigger issue than being at home.... I liked the domestic stuff, cooking and all that. I like that stuff a lot. But I missed work.... As a man you have no status at all if you don't work (Adam).

Adam, a 42-year-old man living in rural Ontario, was a stay-at-home father of three children for a decade. He is one of 70 fathers in the study, as well as part of a larger study of Canadian fathers who self-define as primary caregivers of their children. Adam's children are older now (17, 15, and 11), and he works full-time as an economist for the government, yet he still remembers the difficulties he faced when he was not employed outside of the home. He began his interview by saying that although he "liked the domestic stuff, cooking and all that," it was "not working" that posed such difficulties for him "as a man." In speaking about his typical weekly and daily routine when his first two children, Jeffrey and Bryn, were pre-kindergarten age, he immediately let me know that he also fixed cars while he cared for his young son and daughter:

Jeffrey and I, those first two years, were joined at the hip. And then Bryn and I were joined at the hip for the next while. We did a lot of stuff whereby they would come along with me to do things. Jeffrey would hang around when I was doing things. Like we had a series of old cars. He would hang around while I fixed the cars.

While Adam made a link between caring and repairing cars, all of the fathers' narratives were peppered with references to varied configurations of paid and unpaid work. It was clear that while fathers were at home, they were also carving out complex sets of relations between home, paid and unpaid work, community work, and their own sense of masculinity. In seeking to explore the ways that work and family interact for stay-at-home fathers, this paper argues that they reconstruct the meanings of both, while also demonstrating complex intersections between work, home, community, and masculinity.

The paper makes three key arguments, all of which pull together these intricate connections. First, fathers retain very close links to paid work even when they have temporarily or permanently left a career to care for children. While there are three dominant patterns that characterize fathers' home-work balances, all of the fathers fall under the weight of community scrutiny for being primary caregivers and not primary breadwinners, thus confirming research that has argued that mothers' and fathers' "moral" responsibilities as carers and earners remain differently framed and experienced (Berk, 1985; Finch \& Mason, 1993; McMahon, 1995). Second, where 
fathers have given up a formal investment in the full-time labor force, many replace employment with "self-provisioning" work (Gershuny \& Pahl, 1979; Pahl, 1984; Wallace, 2002; Wallace \& Pahl, 1985) that allows them to contribute economically to the household economy as well as to display masculine practices, both to themselves and their wider community. That is, although stay-at-home fathers "trade cash for care" (Hobson \& Morgan, 2002, p. 1), they also remain connected to traditionally masculine sources of identity such as paid work as well as self-provisioning at home and in the community as public displays of masculinity. Their narratives speak volumes about the ways in which the long shadow of hegemonic masculinity hangs over them. Third and finally, this paper argues that stay-at-home fathers' narratives of emergent and generative practices of caring represent a slow process of critical resistance as they begin to critique concepts of "male time" (Daly, 1996; Davies, 1990, 1994) and market capitalism approaches to work and care (Crittenden, 2001; Folbre, 2001; Williams, 2000).

The paper concludes by suggesting that fathers neither reproduce nor challenge hegemonic masculinity, as has been argued recently by some authors (Brandth \& Kvande, 1998; Dryden, 1999; but see Plantin, Sven-Axel, \& Kearney, 2003). Rather, stay-at-home fathers create new forms of masculinity that, while enacted against a weighty backdrop of hegemonic masculinity, nevertheless incorporate varied aspects of femininities. This paper hints at the need for discussions on men and masculinities to move into new theoretical ground that can assist us in making sense of fathers' living and working in traditional female dominated or symbolically feminine domains. These arguments and findings are based on a qualitative research project with and on Canadian fathers, which will be described below, following a brief outline of the theoretical perspectives informing this work.

\section{THEORETICAL FRAMEWORKS}

My study on fathering is framed by a layered process of investigating and understanding the social worlds inhabited-and co-constructed-by fathers and others. Several overlapping bodies of theory underpin this research, including structuration theory (Bourdieu \& Wacquant, 1992; Connell, 1987; Giddens, 1984), a focus on gender relations and gender regimes (Connell, 1987, 1995, 2000; Smith, 1987, 1996), and a critical realist position (Code, 1993; Sayer, 1999). This work is further framed by symbolic interactionism, studies on fatherhood, and feminist and profeminist work on masculinities and femininities. Only the latter three theoretical approaches will be discussed here since they are most relevant to the findings presented in this paper.

\section{Symbolic InTERACTIONISM AND FAMILY LIFE}

The study that informs this paper is rooted in principles of symbolic interactionism and by a rich tradition of family research that employs such principles (Barker, 1994; Daly, 1996, 2002; Finch \& Mason, 1993; McMahon, 1995). Particular emphasis is placed on attempts to gain people's accounts of their own understandings and actions as well as how they, in turn, interpret these understandings and actions in 


\section{DOUCET}

light of the observations and judgments of other people. A central concept within my work has been that of moral dimensions of fathering and mothering, as well detailed in Janet Finch and Jennifer Mason's work (1993) on negotiating eldercare responsibilities, particularly in their discussion of the interwoven material and moral dimensions of family responsibilities. Drawing on symbolic interactionist ideas, they argue that it is "through human interaction that people develop a common understanding of what a particular course of action will mean: for example, if I offer financial help to my mother in her old age, will it seem generous, or demeaning, or whatever?" (Finch \& Mason, 1993, p. 61). These ideas are applicable to our understandings of mothering and fathering and are intricately connected to "people's identities as moral beings" that "are being constructed, confirmed and reconstructed-identities as a reliable son, a generous mother, a caring sister or whatever it might be" (Finch $\&$ Mason, 1993, p. 170). To add a moral dimension is to incorporate an understanding of the critical role of social networks, how fathers and mothers feel they should act, and how they think others within their community networks will view these actions (Mauthner, 2002; McMahon, 1995).

\section{Studies on Fatherhood and Gender Divisions of Domestic Labour}

My study is also rooted in a burgeoning and excellent body of scholarship on fatherhood and gender divisions of domestic labor. This literature has drawn attention to the continued salience of key obstacles to greater fatherhood involvement including, for example, the role of work in fathers' lives (Deutsch, 1999; Dowd, 2000; Pleck, 1985), parental modeling after one's own father (Coltrane, 1996; Cowan \& Cowan, 1987, Daly, 1993; Pleck, 1985; Snarey, 1993), maternal gatekeeping from wives or female partners (Allen \& Hawkins, 1999; Parke, 1996; Pleck, 1985), co-constructed processes of "doing gender" by both mothers and fathers (Berk, 1985; Coltrane, 1989, 1996; Risman, 1998; West \& Zimmerman, 1987), gender identities and ideologies (Deutsch, 1999; Hochschild, 1989), and discourses of fatherhood (Dienhart, 1998; Lupton \& Barclay, 1997; Mandell, 2002). My work recognizes the validity of all of these facilitating and constraining factors in fathers' involvement but also gives greater emphasis to the role of social networks and the community as well as to the moral assumptions about what it means to be a "good mother" or a "good father," which are held and reinforced within particular communities.

\section{Men ANd Masculinities}

In addition to symbolic interactionist studies on families and research on gender divisions of labour, my work on fathering is also heavily influenced by theoretical literature on men and masculinities. Five points, gleaned from the literature on masculinities, underpin this paper. First, while there has been much debate on the usefulness of the concept "masculinities" (Clatterbaugh, 1998; Hearn, 1996), I hold with Connell that "we need some way of talking about men and women's involvement in the domain of gender "and that masculinities and femininities remain theoretically useful concepts to assist us with making sense of understanding gender relations as well as "gender ambiguity" (Connell, 2000, pp. 16-17). Second, there are a plurality of mas- 
culinities (Brittan, 1989; Hearn \& Morgan, 1990); the meanings of masculinities differ across and within settings, and there are, at the level of practice, varied kinds of relations between different kinds of masculinities (Connell, 2000). Third, masculinities are not essences but occur in social relations where issues of power and difference are at play and where masculinities exist at both the level of agency and structure. As detailed by Connell, "The patterns of conduct our society defines as masculine may be seen in the lives of individuals, but they also have an existence beyond the individual. Masculinities are defined in culture and sustained in institutions" (Connell, 2000, p. 11). A fourth point is that there is a distinction between men and masculinities in that "sometimes masculine conduct or masculine identity goes together with a female body" and, similarly, it is also "very common for a (biological) man to have elements of feminine identity, desire and patterns of conduct" (Connell, 2000, p. 16). These observations are particularly astute when studying men who are engaging in female-dominated or feminine-identified work such as caregiving.

A fifth critical point about masculinity relates to the much discussed concept of "hegemonic masculinity" (Coltrane, 1994; Connell, 1987, 1995, 2000; Kimmel, 1994; Messner, 1997). Traditionally it has been defined as "the most honored or desired" form of masculinity (Connell 2000, p. 10), one that usually aligns itself with traditional masculine qualities of "being strong, successful, capable, reliable, in control. That is $(\mathrm{t})$ he hegemonic definition of manhood is a man in power, a man with power, and a man of power" (Kimmel, 1994, p. 125). Further, as Connell points out, hegemonic masculinity is perhaps most strongly identified "as the opposite of femininity" (Connell, 2000, p. 31). Other forms of masculinity, then, have come to be viewed as subordinated (especially gay masculinities), marginalized (exploited or oppressed groups such as ethnic minorities), and complicit masculinities (those organized around the complicit acceptance of what has come to be termed a "patriarchal dividend" (Connell, 1995, 2000).

While initial discussions of hegemonic masculinity were largely embraced within the community of scholars working on masculinity, the gaps between varied masculinities and between theory and practice have recently begun to emerge. Increased empirical and ethnographic studies of men's lives have shed light on the diverse ways that hegemonic, subordinated, and complicit masculinities can play out in the same setting. In particular, the issue of where caring and fathering fits into this spectrum is one that requires greater attention. Some authors have argued that fathers' caring practices are "adopted by the hegemonic form of masculinity" so that, rather than challenge hegemonic masculinity, caring becomes incorporated into it (Brandth \& Kvande, 1998; Dryden, 1999). Others have recently argued that fathering and caring can be seen as complicit in that fathers can express support for equal parenting while also maintaining more traditional patterns of gender divisions of labor (see Plantin, Sven-Axel, \& Kearney, 2003). Whatever the configuration of diverse masculinities, it is clear that "the interplay between hegemonic and subordinate masculinities suggests the experience of masculinity is far from uniform and that new ways of theorizing these differences need to be developed" (Hearn \& Morgan, 1990, p. 11). Moreover, as indicated by Connell, research on these varied combinations of masculinities "is surely an empirical question, not one to be settled in advance by theory" (Connell, 2000, p. 23). 


\section{DOUCET}

A key question, then, in empirical studies of fathers' lives is how their everyday caring practices confirm or challenge current theoretical understandings of masculinities. Given the continuing salience of the concept of hegemonic masculinity, it is thus worth asking whether or not fathers as carers exhibit subordinated, complicit or hegemonic masculinity. Furthermore, given that hegemonic masculinity is largely associated with the devaluation of the feminine while caring is often equated with feminine practice, what is the relationship between hegemonic masculinity and care? Does fathers' caregiving disrupt the smooth surfaces of hegemonic masculinity? In examining stay-at-home fathers' home-work balances, this question will be explored in this paper.

\section{METHOD}

The arguments developed in this paper draw from a four-year qualitative research study on changing fatherhood. The study's location is Canada where, as in many other industrialized nations, demographic and social factors have translated into the need to redistribute the caring work traditionally assumed by women. My central interest in undertaking this study was to gain a sense of how fathering and mothering were changing against shifting social and economic landscapes. More specifically, I was interested in understanding men's lives and masculinities in the midst of dramatic changes in family life and to engage with David Morgan's compelling claim that "one strategy of studying men and masculinities would be to study those situations where masculinity is, as it were, on the line" (Morgan, 1992, p. 99). My research thus adopted a central case study of men who self-define as primary caregivers (stay-at-home fathers and single fathers) since practices, identities, and discourses of caring remain strongly linked with femininity and women's social lives (Finch \& Mason, 1993; Fox, 2001; Graham, 1983; McMahon, 1995).

\section{SAMPLE}

The larger study on primary caregiving fathers that underpins this paper includes an extensive range of caregiving experiences: 40 single fathers ( 28 sole custody, nine joint custody, and three widowers); 58 stay-at-home fathers (at home for at least one year, including two fathers on paid and unpaid parental leave for one year); and 12 fathers who are single and are/were stay-at-home. In the later stages of the study, I broadened my categories to include 10 shared caregiving fathers - in an effort to include participants who did not necessarily fit into the categories of stay-at-home fathers or single fathers. I was thus able to include gay fathers who did not have legal custody but were active caregivers in their children's lives and several immigrant fathers for whom stay-at-home fathering was not readily compatible with their cultural traditions.

This particular paper focuses on the narratives of 70 fathers who have had the experience of being at home with their children for at least a year. The overwhelming majority of stay-at-home fathers had partners living with them while they were at home (64/70). For the six fathers who were both single and at home, only one father was raising his child without any participation of the child's mother. The 
broad majority of these fathers (53/70 or $76 \%)$ are currently at home with their children whereas 13/70 fathers reflected back to when they were stay-at-home fathers; this latter group of fathers were included in the study so as to gain a sense of the differing experiences and social supports over time for stay-at-home fathers. The fathers who participated in the study saw themselves as primary or shared primary caregivers of children, and 70 fathers were identified as stay-at-home fathers on the basis of their leaving full-time work for a period of a year or more or through arranging their part-time or flexible working around their childcare responsibilities.

The study employed a wide sampling strategy; fathers were recruited through schools and varied community centers (i.e., health-related, community, and ethnic minority groups), in parks and playgrounds, and through placing ads in mainstream Canadian newspapers and in many small community papers. Finally, several fathers were found through snowball sampling whereby one father would provide me with the name of an acquaintance (Miles \& Huberman, 1994). For the 70 stay-at-home fathers whose narratives inform this paper, geographical location is as follows: 46 fathers from Ottawa, the capital city of Canada, a further 12 from other parts of Ontario (two from Ontario cities and 10 from small towns and rural communities), and 12 fathers from six other Canadian provinces. The sample of 70 stay-at-home fathers was very diverse in terms of occupations, social class, and education levels. The sample also includes participation from 10 fathers from visible ethnic minorities, two First Nation fathers, and two gay fathers.

\section{INTERVIEWING AND ANALYSIS}

The interviewing of the 70 stay-at-home fathers occurred between 2000 and 2003 in the following ways: 48 in person (46 face-to-face interviews and two fathers through focus groups), 12 by telephone, and 10 by Web correspondence. Web correspondence was used in order to attract a larger number of fathers to the study as well as to include fathers who might prefer a more limited involvement in the project. In the end, one-third of the Web-based surveys with stay-at-home fathers (i.e., 5/15) were followed up with face-to-face or telephone interviews. The Web-based data were viewed as a supplement to the main data set of in-depth interviews. While approximately one-fourth of the accounts were retrospective, in my analysis I did not treat these accounts differently from the more current ones except to place them in differing social contexts from which these stories are produced.

Fourteen heterosexual couples (with a stay-at-home father and with some diversity along the lines of income, social class, and ethnicity) were interviewed in order to include some mothers' (and couples') views in the study. As the project's lead researcher with a strong belief in the epistemological significance and importance of data collection sites and interactions, I personally interviewed all of the fathers except for one (i.e., 45 of the 46 individual interviews and all of the telephone interviews, focus groups, and couple interviews).

Analysis of the data consisted of several components. First, research assistants carried out in-depth readings of verbatim interview transcripts on their own and then in conjunction with me, utilizing the "Listening Guide" (Brown \& Gilligan, 1992; Mauthner \& Doucet, 1998, 2003). My layered theoretical approach, moving heuristi- 


\section{DOUCET}

cally from individuals to social relationships to wider social structures, was reflected in the multiple readings employed within this analytic strategy. Group discussions of common themes and issues were then conducted, thus producing divergent or shared interpretations of particular transcripts and the subsequent development of 25 case studies. A final stage of analysis entailed a lengthy process of coding (conducted mainly by myself) using the data analysis computer program, ATLAS.ti data analysis brought forth many interesting findings about fathers' experiences of caregiving and their home-work balances; these findings will be illustrated through brief snapshots from the fathers' narratives.

\section{PAID WORK AND HOME}

For the 70 stay-at-home fathers, three sets of patterns, with varying degrees of overlap, characterized their home-work balances. First, there were 12 fathers who had achieved financial and professional success and wanted to take a break from working and/or were seeking to move into another line of work once their children were in school. The overarching commonality with this group of fathers was that they seemed to have achieved their career goals and were looking for other forms of fulfillment, one of which was caring for their children as well as alternative work or leisure interests (e.g., travel, sports, writing). Second, 28 fathers were taking a break from working (as was the case with the two fathers on extended parental leave), were in a clear transition between jobs, were planning to go back to college or university for further education or training, or were currently taking evening courses along this path. Third, 30 fathers were working part-time, flexibly from a home office, or as an employee in their wife/partner's business; of these 30 fathers, 10 (one-third) were both working part-time and in transition between jobs. For all of these stay-at-home fathers, the decision to relinquish full-time employment was a result of a complex mix of factors that included variations of the following themes: their wife/partner having the higher income with employment benefits and a stronger career interest (at this stage of their lives); strong views on the importance of home care; the view that there was a paucity of good childcare facilities in Canada; the cost of childcare; and, in some cases, a child with particular developmental, physical or health needs. Each of the three patterns of home-work balances will be illustrated through a brief case study.

\section{FATHERS WITH WORK SUCCESS: “It's Not LiKe I’m SAYing ‘This Kid Is Holding Me Back’”}

The first pathway to staying at home is well represented in the case study of Rory, a 53-year-old stay-at-home father living in Calgary, Alberta, who gave up his consulting business as quality-control expert on gas pipelines to stay at home with Tristan, who is now seven years old. His wife is a high-level civil servant with the provincial government. At home for four years, he has been president of the school's parent council, takes language courses to assist with French immersion schooling, and cooks a daily special diet for his son, who has debilitating food allergies. He also renovates the home and takes on community work that relates to his son's interests. 
In his words, "The way I see it, if my son is really interested in something, I am really interested in it. If not, I don't have the time." Rory describes the reasoning behind his decision to leave work:

He had been having problems with a stutter and he had been in a home daycare. We were both working. The kids in the daycare all had colds, so I kept him home. Things were pretty slow at work that week. So we decided I would stay home with him that week. His stutter started to get better. The next week he stayed home because he had the cold. Then his stutter got even better. And so I said to my wife, "If this is what it is going to take to get him better, then this is what I will do."

Unlike many of the stay-at-home fathers, Rory seems to have a particular sense of ease about his time at home. At the end of the interview, he adds that they have no debt, the house has been paid off, his wife is younger than he is, it was her turn for her career to take off, and his age is definitely a factor in his sense of ease:

If I had been 20 years old with a son with a stutter and food allergies, I would have responded completely differently. How I would have, I don't know, but I would have responded differently.... I mean, I have traveled; I have worked in many different places. It's not like I'm saying that this kid is holding me back.

Two other fathers can be briefly mentioned here as good illustrations of this pattern of fathers who had achieved work success. Martin, a 42-year-old father of a preschool boy and a second generation Czech Canadian who worked as an insurance adjuster for 20 years, says:

I don't have a huge stigma about not being out there earning the money. Again, it's probably because Denise and I just worked it out in a way ... like, I worked the first 20 years. We joke about it once in a while. Well, I just worked the first 20 years, and I worked to help pay off her student loans and get those paid off, and that was all on my back. I worked since I was 17.

Richard, a French Canadian stay-at-home father of three who was a car mechanic for many years, is quite blunt about his aspirations for a career: "I've done it. I did it before. I made money. I went to work. I used to have expectations and dreams. And I don't want to work anymore."

Fathers like Rory, Martin, and Richard who identified themselves as having met their own standards of employment success were a small part of the study. It was more likely that most of the fathers, as described in the next two sections, were in transition between jobs and/or working part-time. 
DOUCET

\author{
FATHERS IN TRANSITION: \\ “This is Not the Kind of Thing I Want to Do FOR the Rest of My Life"
}

Approximately $37 \%$ of the stay-at-home fathers (28 fathers) were in transition between jobs or careers. Craig, a 40-year old stay-at-home father to triplets, fouryear old Michael and Zachary, and Jonathon who had recently died, typifies the "in transition" father. Although identifying himself as a musician, his paid job for many years was in auto parts as a mechanic. Craig now works at a home hardware store for two evenings a week and Saturdays; his plans are that he is eventually "going back to school in computers." When I ask him how he came to be at home with his sons, he responds:

When my wife became pregnant-my wife is a psychiatric nurse, she has a career... I am a musician from a long time ago, and that's what I like to do primarily. My job was just that, it was not a career, so it was a very easy choice. We looked at it, and I was working in auto parts, mostly car dealerships, and before that I was in forklifts and things like that, parts for these machines. But we looked at it, and when we found out that it was going to be triplets and without even thinking that there would be anything other than three happy normal bouncing kids running around, my salary would have been eaten up by daycare, and I figured well, what the heck, we're going to be in the same boat financially, so I'll stay home until they go to school. That's how we came to the decision; it took us like not even a minute to come to that decision.

A similar story is provided by Andrew, a water supply engineer whose wife has a demanding job that involves international travel. He says: "I was also thinking about getting out of the business anyway. This is not the kind of thing I want to do for the rest of my life. We thought two years. Ideally three." In the end, Andrew stayed home for two years and then went back to a teachers' college when his children were both in school.

Within this group of in-transition fathers, some had lost their jobs, others went through a serious illness that forced them to re-think their career paths at the same time as they were juggling expensive childcare arrangements, and still others found that their jobs were "dead-end" ones that did not justify two stressful jobs and the high cost of childcare. While some men took a break altogether in order to concentrate on the demands of childcare while simultaneously preparing for a new career, others, as described in the next section, took on part-time work or moved their jobs into a more home-based setting.

\title{
FAthers JugGling Paid Work AND CARING: "MY SHOP IS IN THE GARAGE"
}

Of the 70 stay-at-home fathers in the study, 30 fathers were employed in part-time jobs or were working flexible hours from a home-based workplace. Within this 
group, one-third of the fathers were also in transition between careers but were working part-time to supplement the family income. Shahin, a 43-year-old Iranian Canadian, provides a good example of the home-working father. Shahin began staying at home with his son, now six years old, when his wife, a French-Canadian lawyer, went back to work after a four-month maternity leave. A self-employed cabinetmaker, he has a workshop in his garage. In reflecting upon how he and his wife came to the decision that he stay at home, he says:

Well, the decision was, I think, rather simple because my wife makes more money than I do, and I did not want my son to be raised without at least one parent at home... So the decision was made on that basis, based on economical feasibility. It just seemed more logical for me to stay home, especially since I have my own business. I could do at least part-time work.

In his long descriptions about his routine when his son was an infant, he frequently invoked the way in which he juggled work at home and childcare:

My shop is in my garage. It's rather practical. So I had the monitor in the shop.... He had this rocking chair ... you know, you put the baby in there, and it goes back and forth. He loved to sleep in it and it was 45 minutes, I think, the cycle. So I used to run every half an hour and crank it up.

Shahin and 29 other fathers kept their hand in paid work through part-time or home-based working. The range of occupations and creative flexibility within this group was astounding. Of the 30 stay-at-home fathers who work part-time, several diverse examples can be highlighted. Sam is a driving instructor two evenings a week and Saturdays. Jamal, a Somali immigrant father, takes care of his two sons during the day while his wife studies English, and he works nights conducting surveys by phone. Brandon, a sole-custody father, has balanced the raising of his three sons with running his organic farm. Jerome, at home for the past 11 years, works about eight hours a week as office manager in his wife's pediatrician practice in a small Nova Scotia town. Cameron has taken in a foster son, which "allows me to stay at home and look after the kids. Otherwise, we couldn't survive on the one salary." Finally, Harry at home for the past nine years in rural Ontario has taken on many different jobs: "I've helped the neighbors with the hay and, well, ... I do cleaning for two hours a week at the church in Griffith ... I have my chickens and the garden.... And last year I looked after a couple of other kids in the morning well, I got paid for putting them all on the bus."

The patterns described above could be viewed as somewhat similar to those taken by mothers as they seek to find creative ways of combining working and caring. Anita Garey (1999), for example, in her work on women "weaving work and motherhood," details a wide array of patterning for working mothers, including varied kinds of "sequencing" and the "midlife switch" (pp. 165-190). Her work has some parallels with the narratives of the fathers in this study. One large difference, 


\section{DOUCET}

however, is that the majority of fathers in my study felt compelled to talk about paid work in relation to caring, whereas mothers, as described by Garey, were more likely to focus on how their caring responsibilities were not hindered by working. There is thus a slight shift in the balance of emphasis with fathers feeling the weight and pull of moral responsibilities as earners whereas mothers feel pulled by a moral responsibility to care. This is explored more fully in the section that follows.

\section{The Weight of Social Scrutiny and Gendered Moral Responsibilities: "I Felt I WasN’t Being a GoOd MaN"}

Each and every father interviewed referred in some way to the weight of community scrutiny and how he felt social pressure to be earning. Some fathers claimed that they were unaffected by this pressure, but nevertheless they all felt this societal gaze upon them. Peter, a stay-at-home father of two young sons for the past five years, describes this quite well. His former job in desktop publishing was gradually phased out, but he was able to maintain his connection with his former employer and take on contract work for about 12 hours a week from a home office. His wife is a high school teacher. He very much identifies with the "stay-at-home father" label and has done some media appearances on this. Nevertheless, he says:

Despite that fact, I've always - in social occasions, dinner parties, talking with other people, or whatever-other men, I guess, especially - just being able to talk about something I do in the "real world" was kind of important socially - that didn't make me sound limited, or stuck ... to show that I am able to work, although I have chosen to do this.

Marc, a father who began staying at home 15 years ago with his two young sons, also talks about how important it was to be able to say that he was working and that "it was hard at times, and quite honestly I am not sure that I would have done it full time for as long as I did if I had not been working part-time, if I didn't have some sense of worth." He further points to how different moral expectations weigh on women and men and that both he and his wife felt the pressure to fulfill their traditional gendered roles with him "providing more money for the family" and his wife "filling her traditional role." He says:

Back then, I think there were times when I felt I wasn't being a good man, by not providing more money for the family. And that I wasn't doing something more masculine. And there were times when my wife felt that she wasn't filling her traditional role as a wife and a mother.

While Marc mentions how he felt judged for not "being a good man," Archie goes further to suggest that communities cast a suspicious eye toward men at home. Archie, who used to work as a gas service technician and has been home for seven years, says: "For the most part, there is a sense that if a man stays home there is 
something wrong with him, he's lost his job, or he's a little off kilter. It's not their job. They shouldn't be there."

A final example of the expression of this negative social gaze on fathers who relinquish a primary identity as breadwinner is given by Jesse, a freelance artist and stay-at-home father, for two years, of a now three-year-old daughter. He pulls together the ways in which these perceptions are "so engrained" through men's upbringing, how it "can weigh on you" and the particularly gendered quality of this ("It's a guy thing"):

These things are so ingrained in us.... It can weigh on you, those kinds of things. Sometimes I do wonder if people have that sort of perception of me as a stay-at-home father. I am still not sure if there is a widespread acceptance of it. I think some people still wonder, "Why is the father at home? Like he can't earn as much as his partner or something?" I struggle with that, because it is also my own internalized kind of condition, too, that I have this struggle. You know, my background, working class, a strong work ethic. And it's a guy thing.

In referring to "a guy thing," these fathers are implicitly referring to the connections between dominant or hegemonic masculinity and paid work and the associated sense of vertigo that men feel when they relinquish earning as a primary part of their identity (LaBier, 1986; Pahl, 1995; Waddington, Chritcher, \& Dicks, 1998). Fathers remained connected with paid work partly to maintain a link with masculine conceptions of identity and to respond to deeply felt moral precepts that, as one father put it, "There's a certain male imperative to be bringing in money, to feel like you are actually caring for your family, a sense of providing." One of the ways that men deal with these losses is to take on unpaid work that has masculine qualities.

\section{UNPAID WORK AND HOME}

Whatever the status of their relationship with paid work, the overwhelming majority of fathers made it a point to let me know that they were taking on self-provisioning work, mainly "working on the house," and/or doing community work. These two strands of unpaid work will be examined here.

\section{SELF-PROVISIONING: \\ "We Get Together and Talk Tools"}

Most of the stay-at-home fathers spoke about work they were doing on the house, landscaping, carpentry, woodworking or repairing cars. Richard, for example, a 39year-old French Canadian father, draws attention to this issue without even being asked about it. He left his work as an electronic technician two years ago to be at home with his children, now aged seven and two, plus a two-month-old infant. In his joint interview with his wife, Richard takes out a photo album and shows me beforeand-after pictures of his household renovation, saying, "Now you can see how much 


\section{DOUCET}

I've done." He enjoys the domestic routine and has excelled at making award-winning birthday cakes for the kids (and proudly shows photos of his creations); he also makes homemade baby food and does a batch of jams and jellies every fall. When I ask him about the long-term plans, he says, "I am not going back to work," but rather, as he says:

I'll be doing work on the house. Renovations. Cooking, cleaning. They're only gone for six hours. I'll probably be more involved in the school. I'll do these things I've been wanting to do for years. Simple things like organizing my recipes. Organizing my tapes and music.... I have a lot of projects that I want to do in woodworking, but I don't have the time.

Like Richard, many of the stay-at-home fathers in this study reconstruct the meanings of work and home to include unpaid self-provisioning work (Pahl, 1984; Wallace \& Pahl, 1985), specifically "male self-provisioning activities" (Mingione, 1988, p. 560) that include "building, renovation ... carpentry, electrical repairs and plumbing, furniture making, decorating, constructing doors and window frames, agricultural cultivation for own use, repairing vehicles" (see Mingione, 1988, pp. 560-561). While some of these can be viewed as masculine hobbies, which these men would have likely picked up from their fathers or male peers, these are also activities that display or justify men's masculinity and seem to alleviate some of the discomfort men feel with giving up breadwinning.

Fathers' narratives are replete with references to masculine self-provisioning activities. For example, Howard, a stay-at-home father for five years of two schoolaged children, highlights how he likes the renovation but not cleaning: "I do a lot of work around the house. I do the renovation, the house repairs, and a lot of construction.... I don't like cleaning. I like renovations and home repair work." Meanwhile, Luke, who works with mentally challenged adults and has been a stay-at-home parent for 12 years while working nights at a group home, says: "I'm always building something. I'm a renovator. I've renovated the whole house, all on my own." Martin, who often takes his four-year-old son to Home Depot, describes his typical day with Ethan and then notes how the day comes to an end: "And then as soon as Denise gets in, I'm gone! I go down to the basement and work on renovations for an hour, an hour and a half." Tom, a stay-at-home father of three children in rural Quebec, shows me his woodworking shed at the end of our interview. In talking about his typical week, he also adds that in addition to caring for the kids: "I'll call my neighbors whom I do woodworking with, and we'll talk woodworking.... That's a guy thing.... We get together and talk tools, and that is great."

These accounts add to the evidence detailed by family scholars on the intricate intersections between the theoretical concepts and physical sites of home and work. Feminist scholars, for example, have long pointed to how women have often found ways to add to the family economy through household provisioning work (Bradbury, 1984; Folbre, 1991; Land, 1980; Mackintosh, 1988). Moreover, while most studies on divisions of household labor have focused on a range of domestically based tasks such as cooking, cleaning, shopping for groceries, shopping for children's clothes, 
and laundry (i.e., Risman, 1998, p. 59; Brannen \& Moss, 1994; Duetcher, 1999; Hochschild, 1989), my amendment to these studies would be to argue for greater inclusion of nonroutine domestic tasks such as household repair and maintenance.

A further line of argument that bolsters this claim for a wider conception of the domestic is that developed decades ago by Gershuny and Pahl wherein they maintained that households devise complex sets of "household work strategies" based on differing ways of working between the household, the community, and the formal economy (Gershuny \& Pahl, 1979). More recent thinking on "household work strategies" and "self-provisioning" has highlighted how the decision about which work to do oneself and which work to contract out is partly based on "material necessities and preferences," but it is also based on "cultural norms and values as to what one should do oneself and what can be contracted out" (Wallace, 2002, p. 284). For many men in my study, the impulse to take on self-provisioning was partly financial, but it was also part of an effort to justify their being at home through emphasizing more masculine work and hobbies that involve traditional male qualities, such as building, construction, and physical strength. This very much carried over into the community work that men took on, where the emphasis was often on sports and occasionally on traditional masculine roles of physical labor and leadership/management.

\section{COMMUNITY WORK: “They Call Me 'Bob the Builder””}

In addition to unpaid self-provisioning work, men also take on unpaid community work, particularly involvement in school and extracurricular activities. This is well illustrated by Bob, a former sign-maker who lives in rural Quebec. A stay-at-home father for three years of two sons (aged 6 and 4), he left work because of a back injury that affected his ability to keep running his own company. He speaks about having done a lot of "hard physical labor and often outside" for the past 25 years. While at home, he is slowly building up a workshop in the garage and is starting to do renovation jobs for himself and his neighbors. He also has a particular involvement at his son's school:

I'm head of maintenance at my son's kindergarten.... They call me "Bob the Builder" - "fix this, fix that." Every time I go in, they are always asking me to do things.... It takes up my morning so I can't get back to do my own renovation work.

The unpaid community work done by fathers often has gender-neutral tones such as volunteering in the classroom or on school trips, but fathers also emphasize work that has masculine qualities. Building on traditional male interests such as sports (Messner, 1987, 1990) and physical labor, men translated these skills into assets in their caregiving and became involved in recreational sports as organizers and coaches and took on tasks involving physical labor in the classroom. Some fathers also took on leadership positions in school councils and community organizations. Archie, for example, highlights how his position as president of the parentteacher council became "a full time job." 


\section{DOUCET}

It is also important to emphasize that this community work constitutes a part of domestic labor in that it builds bridges between parents, between households, and between households and other social institutions (schools, health settings, community centers). This widening of the domestic is well captured in varied guises and with differing names in feminist work on families and households. Concepts such as "kin work" (Di Leonardo, 1987; Stack, 1974), "servicing work" (Balbo, 1987) and "household service work" (Sharma, 1986) describe the domestic work that goes on beyond the more commonly identified spheres of housework and childcare. This recognition of community work as part of domestic labour is a further insight that this research adds to work on fathering and divisions of domestic labour (see also Doucet, 2000, 2001; Morris, 1995, Hessing, 1993).

It is important to point out that the majority of unpaid work in communities remains in the hands of women. A extensive body of research evidence suggests that women typically do a varied range of work that links the household to the school and to the wider community (Balbo, 1987; Crittenden, 2001; Di Leonardo, 1987; Doucet, 2000, 2001; Stueve \& Pleck, 2003). While Anita Garey has pointed out that "homework, volunteer work and extracurricular activities are ways in which mothers link their children to the public world-and are symbolic arenas in their strategies of being mothers" (Garey, 1999, p. 40), fathers also play a role in children's extracurricular activities such as sporting as well as in community work which emphasizes leadership, sports, construction, and building. In this regard, one area largely overlooked by researchers is the rapidly growing involvement of children in recreation and competitive sports and the very large role that fathers play in this (Doucet, 2004b; Plantin et al., 2003). Many stay-at-home fathers view coaching and assisting in children's sports at school and in the community as a venue that makes their fathering more enjoyable for themselves while also easing community scrutiny of their decision to give up work. Moreover, fathers' involvement in children's lives in a manner that builds on traditional male interests also provides for the possibility of building their own community networks on the basis of traditional areas of male connection such as sports (Messner, 1987, 1990). As argued below, this involvement reflects the way in which fathers seek to distinguish their caring from mothering and to reconstruct particular kinds of "masculine care" (Brandth \& Kvande, 1998).

\section{RECONSTRUCTING CARING, FATHERING, AND MASCULINITIES}

While taking on masculine self-provisioning and/or community work that sometimes involved masculine qualities, what seemed very clear in most fathers' narratives was that they were quite adamant, from within their practices and identities of caring, to distinguish themselves as men, as heterosexual (with the exception of gay fathers), as masculine, and as fathers, not as mothers. In my first focus group with fathers, Sam, stay-at-home father of two for five years, interjected several times, half jokingly: "Well we're still men, aren't we?" Another father, Mitchell, stay-at-home father of three for seven years, made several pointed references in his interview to how he often worked out at a gym and enjoyed "seeing the women in lycra." These men's words add further support to what theorists of work have underlined about men working in nontraditional or female dominated occupations (such as nursing or 
elementary school teaching) and how they must actively work to expel the idea that they might be gay, unmasculine, or not men (Fisher \& Connell, 2002; Sargent, 2000; Williams, 1992). This leads to men finding ways of reinforcing their masculinitysuch as engaging in sports or physical labor so as to maintain masculine affiliations and to exhibit public displays of masculinity (see Bird, 1996). Additionally, the men in my study are attempting to carve out their own paternal and masculine identities within spaces traditionally considered maternal and feminine. These processes of masculine identification and distancing from the feminine occurred in at least three ways.

First, the overwhelming majority of fathers spoke about their efforts to impart a more "masculine quality" to their family care through promoting their children's physical and outdoor activities, independence, risk taking, and the fun and playful aspects of care (see Brandth \& Kvande, 1998; Doucet, 2004a). Second, given that domestic space, the home, is metaphorically configured as a maternal space with feminine connotations of comfort and care (Grosz, 1995; Walker, 2002) many fathers, as described above, more readily identified with the house as something to build and rebuild. Finally, many men also made it a point of saying how they had to "hang out with the guys"- playing traditionally male sports such as hockey or baseball or working with men on activities involving physical labor-so as to balance out the time that they were home caring. Owen, a stay-at-home father of two children for seven years, says: "At the same time I was still needing the men thing. I needed a break from the kids.... I would build sets for the theater. I would hang out with the guys."

A set of theoretical assumptions that can initially assist us in making sense of these processes are feminist theoretical discussions on how men distance themselves from and devalue the feminine (Bird, 1996; Chodorow, 1978; Connell, 1987, 1995, 2000; Johnson, 1988; Thorne, 1993) as well as the concept of hegemonic masculinity. While there have been varied discussions of the meanings and relevance of hegemonic masculinity, most recently the author who penned it, Connell, has boiled it down to being defined partly "as the opposite of femininity" (Connell, 2000, p. 31). These fathers' narratives, as touched upon in this paper, are filled with visible and inchoate contradictions that tell about how fathers are both determined to distance themselves from the feminine, but are also, in practice, radically revisioning masculine care to include some aspects of femininities. In effect their narratives move us beyond the issue of whether they reproduce or challenge hegemonic masculinity (see also Plantin et al., 2003) and, rather, speak to the ways in which they are creating new kinds of masculinities that join together varied configurations of masculinities and femininities.

Audible effects of this revisioning of masculinity can be picked up in these fathers' narratives because they are spoken partly from the borders of the most traditional arena of men's dominance within the "gender order," that of paid work. When men-like the stay-at-home fathers described in this paper-relinquish their identities and practices as full time workers and primary breadwinners, it is inevitable that processes of personal and social readjustment will occur. Perhaps most notable is that fathers' relation to paid work begins to shift, their meanings of work are dramatically altered, and men begin, at least partially, to take on perspectives that are more 


\section{DOUCET}

aligned with women's social positioning (Gilligan, 1982, 1993) and ultimately feminine (Noddings, 2003) or feminist (Friedman, 1993, 2000; Stoljar, 2000; Tronto, 1989) vantage points. There are many instances demonstrating the ways in which these movements occur, three of which will be briefly mentioned here.

First, fathers noted ensuing personal and "generative" (Hawkins, Christiansen, Sargent, \& Hill, 1993; Hawkins \& Dollahite, 1996) changes as they make the shift from worker to carer. Aaron, for example, who used to be a lawyer in a "cutthroat" environment "where you have to be strong," says that "my hard edges have softened" and how he had a steep learning curve "about sharing, feelings, and spending time with them, sort of mellowing out a little." In a similar way, many fathers also find that their time at home gives them the opportunity to reflect on what it is they actually want to do once they return to the work force. Frank, who has been at home with two children for four years, reflects on how this time has been "a real personal growth experience for me" and how he would not have realized that his strengths and interests are in social work and not in accounting where he had previously worked. In his words: "When you're wrapped up in everyday work, you don't reflect on where you are and where you're going."

Second, most fathers mentioned how parenting is the "hardest" or "most difficult" job they have ever done. In the words of Archie, at home for seven years "it's the hardest work I ever done in my whole life," and "its like I have a full-time job, but I don't get paid." From this place where they see that it is "hard"-and yet some of them admit they have "softened" - men also come to appreciate how vitally important caring work is and yet also socially devalued. They thus add their voices to a large chorus of generations of women who have argued for the valuing of unpaid work (Crittenden, 2001; Luxton, 1997; Luxton \& Vosko, 1998; Waring, 1998). As Joe, a Cree stay-at-home father of two, says: “This Mr. Mom businesshere I am complaining about it, and women have been putting up with for a hundred years now." Rory sees caring for his son Tristan as a "job," and more specifically his job: "I know what my job is here.... I will make sure that everything is going right in Tristan's life, because that is my job."

A third way that stay-at-home fathers' relation to paid work changes is that they are adamant that they will remain very involved with their children if and when they go back to full-time employment. While issues of home-work balance have been configured largely as women's issues for decades, with women being the ones who make adjustments in work schedules to accommodate children (Brannen \& Moss, 1991; Hochschild, 1989), fathers at home come to join their female partners in recognizing the need for what researchers have recently termed greater "work-life integration" (Johnson, Lero, \& Rooney, 2001). In two-parent families, many men commented on how their ideal home-work arrangement was that both parents worked part-time or that one parent worked from home. Sam, who has been at home for five years thinks that his wife, a lawyer, should also have the opportunity to stay home for a while. He speaks from the recognition of the benefits of close and sustained connection with his children and the "loss" that occurs if parents do not take this "chance in your life to do that": 
If we had another child, I would want to go back to work and have my wife stay at home. Because it is a chance in your life to do that.... If you don't have a chance to raise them yourself, that is a great loss."

\section{CONCLUSIONS}

Just as Adam, mentioned at the beginning of this paper, let me know how he repaired cars while his children toddled around him, most of the 70 stay-at-home fathers within my larger study on Canadian fathers as primary caregivers, viewed staying at home as a way of combining part-time paid work, "working on the house," caring, and housework. Sometimes these skills extended into the community as fathers often volunteered to coach sports, a venue that allowed them to be involved in their children's lives while also building on a traditional area of male interests. Most of the fathers maintained a connection with paid work, through working part-time, studying part-time for a new career, or taking a break from work in order to carve out a new line of work. The narratives of these fathers and their activities represent the complex intersections between the sites and theoretical concepts of home, work, community and masculinity. Moreover, at a practical level, it could be reasonably argued that the term "stay-at-home" father may be a slight misnomer since most fathers bring together varied configurations of home, paid and unpaid work, and community work. Just as Anita Garey (1999) uses the metaphor of "weaving" to discuss the ways in which mothers weave together complex patterns of employment and motherhood, stay-at-home fathers are in the process of "building" new models of varied employment patterns and fatherhood that represent not only changes in the institution of fatherhood but also suggest potential shifts in social relations between women and men in the social institution of work.

This study contributes to the growing body of excellent work on fatherhood and gender divisions of labor by emphasizing three points. First, this study gives considerable emphasis to the role of social networks and to the community in imparting a "social gaze" on men who stay at home to care for children (see also Doucet, 2000, 2001; Radin, 1982, 1988; Russell, 1983, 1987). The decision to even partially "trade cash for care" (Hobson \& Morgan, 2002, p. 1) places these fathers in a position whereby they are often forced to justify this decision to their peers, kin, work colleagues, and community onlookers, who cast a critical lens on this disruption to the smooth functioning of contemporary gender regimes. This social gaze is rooted in and reinforces moral assumptions that link being a good mother to caring and being a good father to earning (see also Coltrane 1996; Finch \& Mason, 1993; McMahon, 1995). This research also highlights the need for a wider conception of domestic labor to include nonroutine maintenance work and community work. In the case of the former, these are areas where men $d o$ make strong contributions both to domestic labor and to the domestic economy. This is not to underplay arguments that there needs to be greater symmetry between women and men's divisions of domestic labor, still largely weighted on the side of women, but it allows for greater visibility and recognition of what men actually $d o$. In the case of community labor such as involvement in school, community councils, and children's sports, fathers may find 


\section{DOUCET}

a comfortable fit between their gendered upbringing, their sense of masculinity, and their fathering.

This study on stay-at-home fathers also lends itself to several theoretical and political implications about the meanings of work and masculinities. First, I would maintain that these men's stories do not represent any of the key masculinities (complicit, subordinate, or hegemonic) detailed by Connell $(1987,1995)$ but rather, as his recent work highlights, processes "of internal complexity and contradiction" as well as the "dynamics" of changing and evolving masculinities (Connell, 2000, p. 13). In this vein, Connell further writes that "masculinities are not fixed" and are not "homogenous, simple states of being," but rather are "often in tension, within and without" and that "such tensions are important sources of change" (p. 13). Living and working for sustained periods as primary carers while maintaining only a tenuous relation with breadwinning, stay-at-home fathers are in a unique position to create new forms of masculinity. They do so through delicate balancing acts of simultaneously embracing and rejecting both femininity and hegemonic masculinity. They provide "abundant evidence that masculinities do change. Masculinities are created in specific historical circumstances and, as those circumstances change, the gender practices can be contested and reconstructed" (Connell, 2000, pp. 13-14).

Furthermore, fathers' grappling with how to be "a good man" while also recognizing the "softening" that occurs while intimately involved in caregiving, points to the need to move beyond current theorizations around masculinities and to draw on other theoretical tools and approaches. Jeff Hearn and David Morgan (199) underline that "the experience of masculinity is far from uniform and that new ways of theorizing these differences need to be developed" (p. 11; emphasis added). Our understandings of men's lives and their subjective conceptions of masculinities could, for example, benefit from longstanding feminist debates on the intricate linkages between theoretical and empirical concepts of justice and care, autonomy and connection, and individual rights and relational responsibilities (Benhabib, 1992; Doucet, 1995; Gilligan, 1988; Kittay, 1999; Minow \& Shanley, 1996; Sevenhuijsen, 1998, 2000; Tronto, 1993, 1995). That is, men's practices and identities of caregiving go beyond current conceptions of masculinities and femininities and may reflect philosophical and political concepts of self, identity, and subjectivity that embrace varied degrees of dependence, independence, and interdependence as well as varied versions of "relational autonomy" (Friedman, 1993, 2000). This study hints at the need for greater exploration of this line of theoretical inquiry.

A final concluding point refers to the political implications that can be drawn from this work and to the potential role that men could play in the social recognition and valuing of unpaid work (Armstrong \& Armstrong, 1993; Doucet, 2004a; Luxton, 1980, 1997; Luxton \& Vosko, 1998). Freed somewhat from the breadwinner imperative that is the norm for most men in most societies, the stay-at-home fathers in this study can be viewed as representing some of what Karin Davies refers to in her Swedish study of women, work and time. Davies argues that decisions to work part-time or to take time off from work constitute "breaking the pattern" (p. 217) out of "wage labor as the over-riding structure and an unconditional adherence to male time" (Davies, 1990, p. 208). She maintains that "by limiting the time spent in wage labor, a soil is provided whereby visions of what is important to fight and strive for 
can find space" (p. 208). While writing about women two decades ago, the views of Davies as applied to men have a particularly powerful effect because the "the overriding structure" and "male time" she refers to have strong connections with masculinity, especially hegemonic masculinity. It is men's overall privileged access to the rewards of paid employment and their concurrent lesser role in the care of dependent others that partly account for the overall dominance and associated "patriarchal dividend" (Connell, 1995) from which men benefit. The slow process of critical resistance documented here by fathers as they critique concepts of "male time" constitutes some unraveling of their relation to the structural effects of hegemonic masculinity.

Nevertheless, these stories are marginal ones; they sit quietly on the borders of most men's lives in most contemporary societies. Connell poignantly cautions that "the gender order does not blow away at a breath" and "the historical process around masculinity is a process of struggle in which, ultimately, large resources are at stake" (2000, p. 14). We are reminded of the need to move beyond these vignettes of everyday caring and the generative changes that ensue to focus on wider social relations and the need for greater structural changes and policy measures to assist both women and men in achieving work-life integration (Folbre, 1994, 2001; Fraser, 1997; Hobson, 2002; Plantin et al., 2003). While Davies' work highlights how "it is up to women to exert influence" in this vein since they are more likely to have "experience of rejecting male time" and thus "concrete knowledge and understanding of how we can produce and reproduce new forms of daily life ... which are not so oppressive" (1990, p. 247), this study suggests that stay-at-home fathers are also lodged in this distinctive position as well. Indeed, adding father's voices to these issues can also "exert influence" very loudly indeed, both theoretically and politically.

\section{REFERENCES}

Allen, S. M., \& Hawkins, A. J. (1999). Maternal gatekeeping: Mothers' beliefs and behaviors that inhibit greater father involvement in family work. Journal of Marriage and the Family, 61, 199-212.

Armstrong, P., \& Armstrong, H. (1993). The double ghetto (3rd ed.). Toronto: McClelland and Stewart.

Balbo, L. (1987). Crazy quilts: Rethinking the welfare state debate from a woman's point of view. In A.S. Sassoon (Ed.), Women and the State (pp. 45-71). London: Unwin Hyman.

Barker, R.W. (1994). Lone fathers and masculinities. Avebury, UK: Aldershot. Benhabib, S. (1992). Situating the self. Cambridge: Polity Press.

Berk, S.F. (1985). The gender factory: The apportionment of work in American households. New York: Plenum.

Bird, S.R. (1996). Welcome to the men's club: Homosociality and the maintenance of hegemonic masculinity. Gender \& Society, 19(2), 120-132.

Bourdieu, P., \& Wacquant, L. (1992). An invitation to a reflexive sociology. Chicago: University of Chicago Press.

Bradbury, B. (1984). Pigs, cows and boarders: Non-wage forms of survival among Montreal families, 1861-1881. Labour/Le Travail, 14, 9-46. 


\section{DOUCET}

Brandth, B., \& Kvande, E. (1998). Masculinity and child care: The reconstruction of fathering. The Sociological Review, 46(2), 293-313.

Brannen, J., \& Moss, P. (1991). Managing mothers: Dual earner households after maternity leave. London: Unwin Hyman.

Brittan, A. (1989). Masculinity and power. Oxford: Basil Blackwell.

Brown, L.M., \& Gilligan, C. (1992). Meeting at the crossroads: Women's psychology and girls' development. Cambridge, MA: Harvard University Press.

Chodorow, N. (1978). The reproduction of mothering. Berkeley and Los Angeles: University of California Press.

Clatterbaugh, K. (1998). What is problematic about masculinities? Men and Masculinities, 1(1), 24-45.

Code, L. (1993). Taking subjectivity into account. In L. Alcoff \& E. Potter (Eds.), Feminist epistemologies (pp. 15-48). New York and London: Routledge.

Coltrane, S. (1989). Household labor and the routine production of gender. Social Problems, 36(5), 473-490.

Coltrane, S. (1994). Theorizing masculinities in contemporary social science. In H. Brod \& M. Kaufman (Eds.), Theorizing masculinities (pp. 39-60). Thousand Oaks: Sage Publications.

Coltrane, S. (1996). Family man: fatherhood, housework, and gender equity. Oxford: Oxford University Press.

Connell, R.W. (1987). Gender and power. Cambridge, UK: Polity Press.

Connell, R.W. (1995). Masculinities. London: Polity Press.

Connell, R.W. (2000). The men and the boys. Berkeley: University of California Press.

Cowan, C.P., \& Cowan, P.A. (Eds.). (1987). Men's involvement in parenthood: Identifying the antecedents and understanding the barriers. Hillsdale, NJ: Erlbaum.

Crittenden, A. (2001). The price of motherhood: Why the most important job in the world is still the least valued. New York: Henry Holt and Company.

Daly, K. (1993). Reshaping fatherhood: Finding the models. Journal of Family Issues, 14, 510-530.

Daly, K. (1996). Families and time: Keeping pace in a hurried culture. Thousand Oaks, CA: Sage Publications.

Daly, K. (2002). Time, gender, and the negotiation of family schedules. Symbolic Interaction, 25(3), 323-342.

Davies, K. (1990). Women, time and weaving the strands of everyday life. Avebury, UK: Gower Publishing Company.

Davies, K. (1994). The tension between process time and clock time in care work: The example of day nurseries. Time and Society, 3, 276-303.

Deutsch, F.M. (1999). Halving it all: How equally shared parenting works. Cambridge, MA: Harvard University Press.

Di Leonardo, M. (1987). The female world of cards and holidays: Women, families and the world of kinship. Signs, 12(3), 440-453.

Dienhart, A. (1998). Reshaping fatherhood: The social construction of shared parenting. London: Sage Publications.

Doucet, A. (1995). Gender equality and gender differences in household work and parenting. Women's Studies International Forum, 18(3), 271-284. 
Doucet, A. (2000). "There's a huge difference between me as a male carer and women": Gender, domestic responsibility, and the community as an institutional arena. Community Work and Family, 3(2), 163-184.

Doucet, A. (2001). "You see the need perhaps more clearly than I have": Exploring gendered processes of domestic responsibility. Journal of Family Issues, 22, 328-357.

Doucet, A. (2004a). Fathers and the responsibility for children: A puzzle and a tension. Atlantis: A Women's Studies Journal, 28(2), 103-114.

Doucet, A. (2004b). Do men mother? Manuscript submitted for publication.

Dowd, N.E. (2000). Redefining fatherhood. New York: New York University Press.

Finch, J., \& Mason, J. (1993). Negotiating family responsibilities. London: Routledge.

Fisher, M., \& Connell, R.W. (2002). Masculinities and men in nursing. Paper presented at the 3rd College of Health Sciences Research Conference "From Cell to Society", Leura, Australia.

Folbre, N. (1991). The unproductive housewife: Her evolution in nineteenth century thought. Signs, 16(3), 463-484.

Folbre, N. (1994). Who pays for the kids? Gender and the structures of constraint. London: Routledge, Chapman and Hall.

Folbre, N. (2001). The invisible heart: Economics and family values. New York: The New Press.

Fox, B. (2001). The formative years: How parenthood creates gender. Canadian Review of Sociology and Anthropology, 38(4), 373-390.

Fraser, N. (1997). After the family wage: A postindustrialist thought experiment. In N. Fraser (Ed.), Justice interruptus: Critical reflections of the "postsocialist condition" (pp. 41-66). New York: Routledge.

Friedman, M. (1993). Beyond caring: The demoralization of gender. In M.J. Larrabee (Ed.), An ethic of care: Feminist and interdisciplinary perspectives (pp. 258-274). London: Routledge.

Friedman, M. (2000). Autonomy, social disruption and women. In C. Mackenzie \& N. Stoljar (Eds.), Relational autonomy: Feminist perspectives on autonomy, agency, and the social self (pp. 35-51). Oxford: Oxford University Press.

Garey, A.I. (1999). Weaving work and motherhood. Philadelphia: Temple University Press.

Gershuny, J.I., \& Pahl, R.E. (1979). Work outside employment: Some preliminary speculations. New Universities Quarterly, 34, 120-135.

Giddens, A. (1984). The constitution of society: Outline of the theory of structuration. Cambridge, UK: Polity Press.

Gilligan, C. (1982). In a different voice: Psychological theory and women's development. Cambridge, MA: Harvard University Press.

Gilligan, C. (1988). Remapping the moral domain: New images of the self in relationship. In C. Gilligan, J.V. Ward, J.M. Taylor, \& B. Bardige (Eds.), Mapping the moral domain: A contribution of women's thinking to psychological theory and education (pp. 3-19). Cambridge, MA: Harvard University Press.

Gilligan, C. (1993). Reply to critics. In M.J. Larrabee (Ed.), An ethic of care: Feminist and interdisciplinary perspectives (pp. 207-214). New York: Routledge. 


\section{DOUCET}

Graham, H. (1983). Caring: A labor of love. In J. Finch \& D.A. Groves (Eds.), A labor of love: Women, work and caring (pp. 13-30). London: Routledge and Kegan Paul.

Grosz, E. (1995). Space, time and perversion. London: Routledge and Kegan Paul.

Hawkins, A.J., Christiansen, S.L., Sargent, K.P., \& Hill, E.J. (1993). Rethinking fathers' involvement in child care: A developmental perspective. Journal of Family Issues, 14, 531-549.

Hawkins, A.J., \& Dollahite, D.C. (1996). Generative fathering: Beyond deficit perspectives. Thousand Oaks, CA: Sage Publications.

Hearn, J. (1996). Is masculinity dead? A critique of the concept of masculinity/masculinities. In M. Mac an Ghaill (Ed.), Understanding masculinities (pp. 202217). Buckingham, UK: Open University Press.

Hearn, J., \& Morgan, D.H.J. (1990). Men, masculinities and social theory. In D.H.J. Morgan (Ed.), Men, masculinities and social theory (pp. 1-17). London: Unwin Hyman.

Hobson, B. (Ed.). (2002). Men, masculinities and the social politics of fatherhood. Cambridge, UK: Cambridge University Press.

Hobson, B., \& Morgan, D.H.J. (2002). Introduction: Making men into fathers. In B. Hobson (Ed.), Men, masculinities and the social politics of fatherhood. (pp. 121). Cambridge, UK: Cambridge University Press.

Hochschild, A.R. (1989). The second shift. New York: Avon Books.

Johnson, K.L., Lero, D.S., \& Rooney, J.A. (2001). Work-life compendium 2001: 150 Canadian statistics on work, family and well-being. Guelph, Ontario: Centre for Families, Work and Well-Being, University of Guelph.

Johnson, M.M. (1988). Strong mothers, weak wives: The search for gender equality. Berkeley: University of California Press.

Kimmel, M.S. (1994). Masculinity as homophobia: Fear, shame and silence in the construction of gender identity. In H. Brod \& M. Kaufman (Eds.), Theorizing masculinities (pp. 119-141). Thousand Oaks, CA: Sage Publications.

Kittay, E.F. (1999). Love's labor: Essays on women, equality and dependency. Oxford: Oxford University Press.

LaBier, D. (1986). Modern madness: The hidden link between work and emotional conflict. New York: Simon and Schuster.

Land, H. (1980). The family wage. Feminist Review, 6, 55-77.

Lupton, D., \& Barclay, L. (1997). Constructing fatherhood: Discourses and experiences. London: Sage Publications.

Luxton, M. (1980). More than a labor of love: Three generations of women's work in the home. Toronto: Women's Press.

Luxton, M. (Ed.). (1997). Feminism and families: Critical policies and changing practices. Halifax: Fernwood Publishing.

Luxton, M., \& Vosko, L. (1998). The Census and women's work. Studies in Political Economy, 56, 49-82.

Mackintosh, M.M. (1988). Domestic labour and the household. In R.E. Pahl (Ed.), On work: Historical, comparative and theoretical approaches (pp. 392-406). Oxford: Basil Blackwell. 
Mandell, D. (2002). Deadbeat dads: Subjectivity and social construction. Toronto: University of Toronto Press.

Mauthner, N.S. (2002). The darkest days of my life: Stories of postpartum depression. Cambridge, MA: Harvard University Press.

Mauthner, N.S., \& Doucet, A. (1998). Reflections on a voice centred relational method of data analysis: Analysing maternal and domestic voices. In J. Ribbens $\&$ R. Edwards (Eds.), Feminist dilemmas in qualitative research: Private lives and public texts (pp. 119-144). London: Sage Publications.

Mauthner, N.S., \& Doucet, A. (2003). Reflexive accounts and accounts of reflexivity in qualitative data analysis. Sociology, 37(3), 413-431.

McMahon, M. (1995). Engendering motherhood: Identity and self-transformation in women's lives. New York: The Guilford Press.

Messner, M.A. (1987). The meaning of success: The athletic experience and the development of male identity. In H. Brod (Ed.), The making of masculinities: The new men's studies (pp. 193-209). Boston: Allen and Unwin.

Messner, M.A. (1990). Boyhood, organized sports, and the construction of masculinities. Journal of Contemporary Ethnography, 18(4), 416-444.

Messner, M.A. (1997). Politics of masculinities: Men in movements. Thousand Oaks, CA: Sage Publications.

Miles, M.B., \& Huberman, M.A. (1994). Qualitative data analysis: An expanded sourcebook. London: Sage Publications.

Mingione, E. (1988). Work and informal activities in urban southern Italy. In R.E. Pahl (Ed.), On work: Historical, comparative and theoretical approaches (pp. 548-578). Oxford: Basil Blackwell.

Minow, M., \& Shanley, M.L. (1996). Relational rights and responsibilities: Revisioning the family in liberal political theory and law. Hypatia, 11(1), 4-29.

Morgan, D.H.J. (1992). Discovering men. London: Routledge.

Noddings, N. (2003). Caring: A feminine approach to ethics and moral education (2nd ed.). Berkeley: University of California Press.

Pahl, R.E. (1984). Divisions of labour. Oxford: Basil Blackwell.

Pahl, R.E. (1995). After success: Fin-de-siecle anxiety and identity. Cambridge, UK: Polity.

Parke, R.D. (1996). Fatherhood. Cambridge, Massachusetts: Harvard University Press.

Plantin, L., Sven-Axel, M., \& Kearney, J. (2003). Talking and doing fatherhood: On fatherhood and masculinity in Sweden and England. Fathering, 1(1), 3-26.

Pleck, J.H. (1985). Working wives, working husbands. London: Sage.

Radin, N. (1982). Primary caregiving and role sharing fathers. In M.E. Lamb (Ed.), Non-traditional families: Parenting and child development (pp. 173-204). Hillsdale, NJ: Erlbaum.

Radin, N. (1988). Primary caregiving fathers of long duration. In P. Bronstein \& C. P. Cowan (Eds.), Fatherhood today: Men's changing roles in the family (pp. 127-143). New York: John Wiley and Sons.

Risman, B.J. (1998). Gender vertigo: American families in transition. New Haven: Yale University Press. 


\section{DOUCET}

Russell, G. (1983). The changing role of fathers. St. Lucia, Australia: University of Queensland Press.

Russell, G. (1987). Problems in role reversed families. In C. Lewis \& M. O'Brien (Eds.), Reassessing fatherhood: New observations on fathers and the modern family (pp. 161-182). London: Sage Publications.

Sargent, P. (2000). Real men or real teachers? Contradictions in the lives of men elementary teachers. Men and Masculinities, 2(4), 410-433.

Sayer, A. (1999). Realism and social science. London: Sage Publications.

Sevenhuijsen, S. (1998). Citizenship and the ethics of care: Feminist considerations on justice, morality and politics. London: Routledge.

Sevenhuijsen, S. (2000). Caring in the third way: The relation between obligation, responsibility and care in Third Way discourse. Critical Social Policy: A Journal of Theory and Practice in Social Welfare, 25(1), 5-38.

Smith, D. (1987). The everyday world as problematic: A feminist sociology. Milton Keynes, UK: Open University Press.

Smith, D. (1996). Telling the truth after postmodernism. Studies in Symbolic Interaction, 19(3), 171-202.

Snarey, J. (1993). How fathers care for the next generation. Cambridge, Massachusetts: Harvard University Press.

Stoljar, N. (2000). Autonomy and feminist intuition. In C. Mackenzie \& N. Stoljar (Eds.), Relational autonomy: Feminist perspectives on autonomy, agency, and the social self (pp. 94-111). New York and Oxford: Oxford University Press.

Stueve, J.L., \& Pleck, J.H. (2003). Fathers' narratives of arranging and planning: Implications for understanding parental responsibility. Fathering, 1(1), 51-70.

Thorne, B. (1993). Gender play: Girls and boys in school. Buckingham, UK: Open University Press.

Tronto, J. (1989). Women and caring: What can feminists learn about morality from caring? In A. M. Jaggar \& S. Bordo (Eds.), Gender/body/knowledge: Feminist reconstructions of being and knowing (pp. 172-187). New Brunswick, NJ: Rutgers University Press.

Tronto, J. (1993). Moral boundaries: A political argument for an ethic of care. New York: Routledge.

Tronto, J. (1995). Care as a basis for radical political judgements (Symposium on Care and Justice). Hypatia, 10(2), 141-149.

Waddington, D., Chritcher, C., \& Dicks, B. (1998). "All jumbled up": Employed women with unemployed husbands. In J. Popay, J. Hearn, \& J. Edwards (Eds.), Men, gender divisions and welfare (pp. 231-258). New York: Routledge.

Walker, L. (2002). Home making: An architectural perspective. Signs: Journal of Women in Culture and Society, 27(3), 823-836.

Wallace, C.D. (2002). Household strategies: Their conceptual relevance and analytical scope in social research. Sociology, 36(2), 275-292.

Wallace, C.D., \& Pahl, R.E. (1985). Household work strategies in an economic recession. In N. Redclift \& E. Mingione (Eds.), Beyond employment (pp. 189227). Oxford: Basil Blackwell.

Waring, M. (1998). If women counted. San Francisco: Harper and Row.

West, C., \& Zimmerman, R. (1987). Doing gender. Gender \& Society, 1, 30-37. 
“IT’s Almost Like I Have A JoB"

Williams, C.L. (1992). The glass escalator: Hidden advantage for men in the "female" professions. Social Problems, 39(3), 253-267.

Williams, J. (2000). Unbending gender: Why family and work conflict and what to do about it. Oxford: Oxford University Press. 